\title{
Environmental factors can influence dengue reported cases
}

\author{
Marco Antonio F. Carneiro ${ }^{1}$, Beatriz da C. A. Alves ${ }^{1 *}$, Flávia de Sousa Gehrke ${ }^{1}$, José Nuno Domingues ${ }^{2}$, \\ Nelson Sá ${ }^{2}$, Susana Paixão ${ }^{2}$, João Figueiredo ${ }^{3}$, Ana Ferreira $^{2}$, Cleonice Almeida $^{4}$, Amaury Machi $^{4}$, Eriane Savóia $^{4}$, \\ VÂnia Nascimento ${ }^{1}$, Fernando Fonseca ${ }^{1,5}$ \\ ${ }^{1}$ Faculdade de Medicina do ABC (FMABC), Santo André, SP, Brazil \\ ${ }^{2}$ Environmental Health - IPC, EsTesC, Coimbra Health School, Coimbra, Portugal \\ ${ }^{3}$ Departamento das Ciências Complementares - IPC, EsTesC, Coimbra Health School, Coimbra, Portugal \\ ${ }^{4}$ Gestão de Saúde Ambiental, FMABC, Santo André, SP, Brazil \\ ${ }^{5}$ Biological Science Department, Universidade Federal de São Paulo (Unifesp), Diadema, SP, Brazil
}

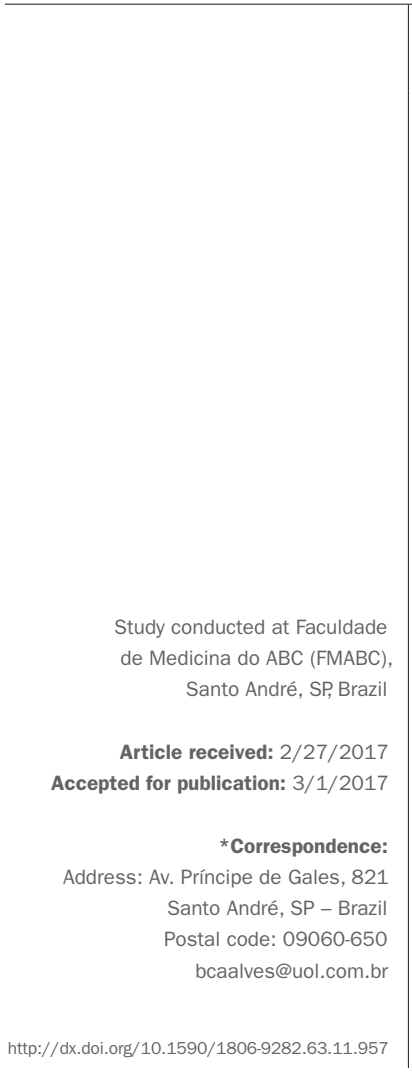

\section{INTRODUCTION}

Severe climate alterations, a major concern worldwide, have been occurring over the past few centuries. Such changes derive from a global warming effect that leads to ecological imbalance. ${ }^{1}$ The World Health Organization (WHO) sees health problems related to climate changes as one of the greatest issues of the $21^{\text {st }}$ century. These alterations directly interfere with the natural environment, and upon relating them with climate and tropical diseases, it can be noted that changes in temperature alter the ecosystem balance, contributing to an increase in the transmission of diseases by vectors, including dengue at the top of the list. ${ }^{1,2}$

Dengue is an infectious disease caused by an RNA virus. Four virus serotypes have been identified so far: DEN-1, DEN-2, DEN-3 and DEN-4. The disease is characterized by variable febrile periods, clinically classified as dengue fever (DF) or classic dengue fever. Acute manifestations of the disease, classified as dengue hemorrhagic fever (DHF) and dengue shock syndrome (DSS) may lead the patient to death. ${ }^{3}$

Aedes aegypti mosquitoes are the main vector for dengue virus. The species is adapted not only to the domestic environment but also to the demographic growth and internal and international processes of $\mathrm{mi}$ gration of people. These factors, along with aspects such as rainfall, humidity and temperature variation, favor the spread of the mosquito and the dissemination of virus serotypes. The existence of suitable sites for the breeding of mosquitoes (water storage) in urban areas completes the scenario. ${ }^{4}$ 
Dengue transmission peaks may be related to an increase in the survival rate of the adult vector under favorable temperature and humidity conditions in the rainy season. This survival rate enables the infected female the possibility to complete the virus replication cycle, thus becoming an infection vector. ${ }^{5}$

Climate variation among the municipalities, associated with a temporal dimension that allows for the incorporation of isolated phenomena of climate change patterns, are essential elements for the conduction of this study. ${ }^{6}$

The Greater $\mathrm{ABC}$ area comprises seven municipalities, namely Santo André, São Caetano do Sul, São Bernardo do Campo, Diadema, Mauá, Ribeirão Pires and Rio Grande da Serra (Table 1). Located in São Paulo's southeast area, it concentrates major industrial complexes and highly urbanized areas, but also plenty of green spaces and nature reserves, intended for environmental preservation, with water reservoirs that supply the whole metropolitan area.

\begin{tabular}{|c|c|c|}
\hline Municipality & Population & GDP per capita (BRL) \\
\hline Santo André & 673,900 & $21,843.91$ \\
\hline São Caetano do Sul & 149,295 & $68,649.65$ \\
\hline São Bernardo do Campo & 810,203 & $35,680.05$ \\
\hline Diadema & 386,039 & $30,332.87$ \\
\hline Mauá & 444,136 & $13,752.84$ \\
\hline Rio Grande da Serra & 44,084 & $8,536.14$ \\
\hline Ribeirão Pires & 113,043 & $13,347.20$ \\
\hline
\end{tabular}

*Brazilian Census Bureau (IBGE), 2010.

GDP: gross domestic product.

Due to the variety of manufacturing industries, these industrialized municipalities attract a great number of people who seek better life conditions. São Caetano do Sul has the highest gross domestic product (GDP) per capita, and General Motors, located in this municipality, directly affects the population's quality of life. Nevertheless, according to a study on the environmental impact caused by the industrial conglomerate, which generates particulate matters (PM10) and may affect climatic conditions, is important. Moreover, our study seeks to relate these impacts to the spread and dissemination of the dengue mosquito.

São Paulo is the industrial and financial center of Brazil, and the $\mathrm{ABC}$ area is where most manufacturing plants are located. Therefore, it is important to conduct studies on climate change as well as air pollution rates with the resulting impact on society in general, and more specifically on public health. Investigations such as these may serve as a database for better planning and prevention against vector-borne diseases.

In sum, our study aims to establish a correlation between dengue incidence and environmental-climatic conditions through the analysis of the number of notified dengue cases between the years 2010 and 2013 in the Greater ABC area, in São Paulo, and the following meteorological data: humidity, temperature and particulate matters less than 10 microns in diameter (PM10).

\section{Method}

A cross-sectional observational study with an ecological planning model was carried out. Data were collected, and the following variables were used for epidemiological and entomological investigation: space (regions), time (year, month and seasons), meteorology (temperature-humidity index) and the chronological distribution of the disease.

The study covered the period between January 2010 and December 2013 in the Greater ABC area in São Paulo. Data were collected from the National Meteorological Institute, the Environmental Technology and Sanitation Agency (Cetesb, in the Portuguese acronym), ${ }^{7}$ the Epidemiological Surveillance Service - Dengue Prevention Department in Santo André and the Epidemiological Surveillance Center (CVE, in the Portuguese acronym). ${ }^{8}$

The data were analyzed in order to verify their relation during the periods of incidence at a certain period of time that allows for the investigation of the resulting phenomena of the interactions with the environment. Pearson correlation was used to analyze the association between humidity, temperature and PM10 regarding the incidence of cases of the disease per year. Statistical significance was reached at $\mathrm{p}<0.05$. IBM SPSS Statistics 19 software was used.

\section{Results}

According to the numbers obtained from Cetesb and the CVE, the year of highest incidence of dengue was 2010, with 577 cases in total, which corresponds to an incidence of 2.22 cases per 10,000 inhabitants (Table 2). In 2011, this number slightly decreased to 555 cases. In 2012, however, a total of 125 cases were notified ( 0.48 cases $/ 10,000$ population), which represents a sharp drop in relation to the previous year (22.5\%). Therefore, it is important to point out that the number of cases reported in 2012 was atypical compared with the previous years, and even 2013, when the number of notified cases rose to 402 .

Santo André, São Bernardo do Campo, São Caetano do Sul and Diadema are the most industrialized municipalities in the area, and they are the ones with the highest rate of dengue notifications. The highest incidence 
rate per municipality was registered in Diadema, with 14.89 cases per 10,000 inhabitants.

\section{TABLE 2 Number of dengue cases in the Greater ABC area.}

\begin{tabular}{|c|c|c|c|c|c|}
\hline \multirow[t]{2}{*}{ Municipality } & \multicolumn{4}{|l|}{ Year } & \multirow{2}{*}{$\begin{array}{l}\text { Incidence } \\
\text { rate* }\end{array}$} \\
\hline & 2010 & 2011 & 2012 & 2013 & \\
\hline Santo André & 180 & 71 & 40 & 106 & 5.45 \\
\hline São Bernardo do Campo & 158 & 136 & 36 & 170 & 6.7 \\
\hline São Caetano do Sul & 31 & 30 & 9 & 27 & 6.49 \\
\hline Diadema & 177 & 295 & 26 & 77 & 14.89 \\
\hline Mauá & 21 & 19 & 12 & 16 & 1.53 \\
\hline Ribeirão Pires & 7 & 1 & 2 & 3 & 1.15 \\
\hline Rio Grande da Serra & 3 & 3 & 0 & 3 & 2.04 \\
\hline Total & 577 & 555 & 125 & 402 & \\
\hline
\end{tabular}

According to the data supplied by the CVE, the months of January, February, March, April and May (from 2010 to 2013) were the ones with the highest number of notified cases. As a result, an analysis of climatic and environmental factors during those months was carried out so that a possible relation between these variables and a higher proliferation and notification of dengue cases could be established.

Figure 1 presents an extremely close relation between temperature values and the notified dengue cases. It can be observed that temperature peaks coincided with epidemic peaks between the months of January and May. Nevertheless, while this relation is quite clear, there was no statistically significant association between them.
There was, however, a statistically significant association of humidity and PM10 with dengue cases ( $\mathrm{p}=0.003$ and $\mathrm{p}=0.001$, respectively) (Table 3 ). As for humidity, this variable had a positive correlation (0.163), i.e., the greater the humidity, the higher the number of dengue cases. In other words, whenever humidity rates reached their highest values, there was an increase in number of registered cases in the area. Interestingly, PM10 had a negative Pearson correlation $(-0,213)$, showing that lower PM10 values coincided with a higher number of dengue cases. Air pollution could therefore be the reason for reported dengue cases.

\begin{tabular}{|c|c|c|c|c|}
\hline & & Temperature & Humidity & PM10 \\
\hline \multirow{3}{*}{$\begin{array}{l}\text { Dengue } \\
\text { cases }\end{array}$} & Pearson correlation & 0.093 & 0.163 & -0.213 \\
\hline & p-value & 0.088 & 0.003 & 0.001 \\
\hline & $\mathrm{N}$ & 336 & 336 & 240 \\
\hline
\end{tabular}

\section{Discussion}

In scientific terms, there is a relation between temperature and humidity, so that relative humidity can be defined as the ratio of the amount of water vapor in the air at a specific temperature to the maximum amount that the air could hold at that temperature. At higher temperatures the air may contain more water vapor than the same volume of air at lower temperatures. ${ }^{9}$

Our findings show that the months presenting temperature and humidity peaks, namely January, February,

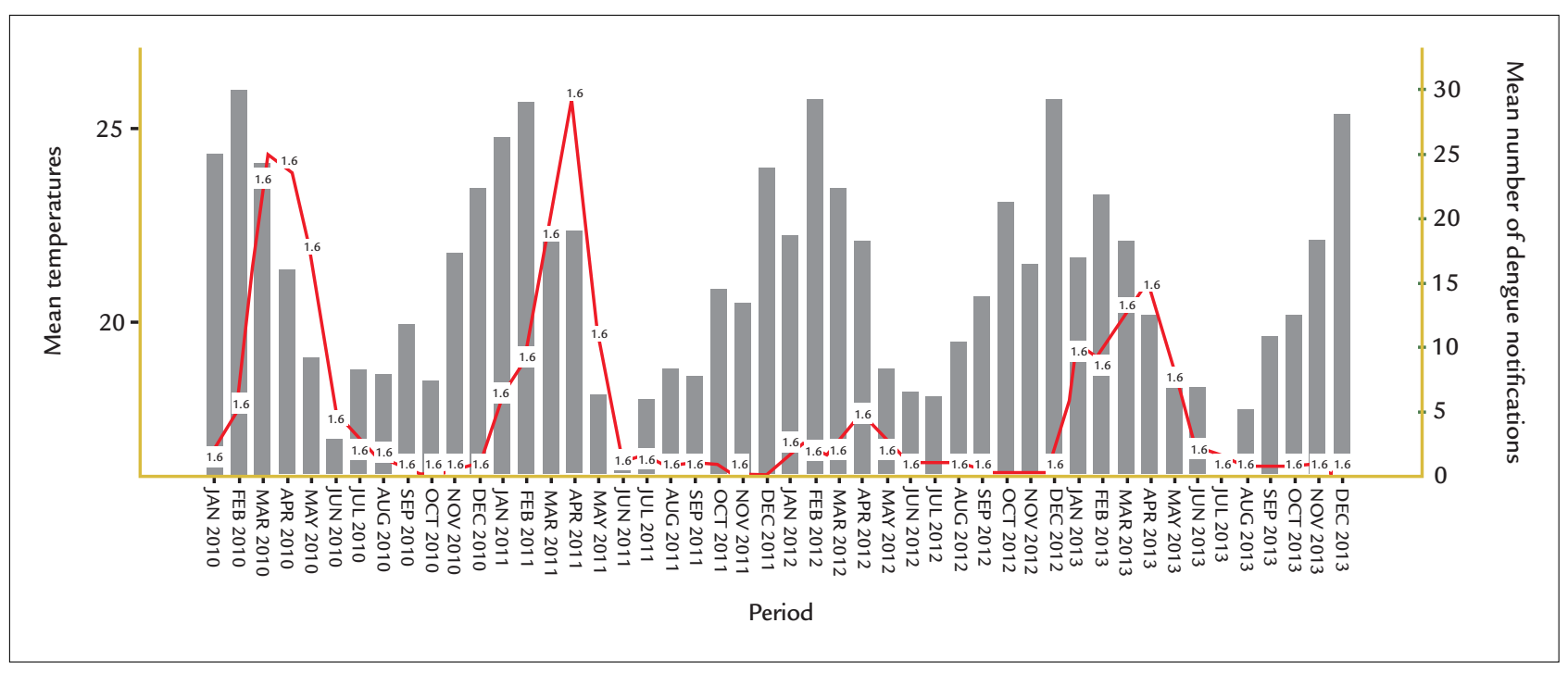

FIGURE 1 Mean temperatures and number of dengue notifications in the Greater ABC area between 2010 and 2013. 
March, April and May, also had more notifications of dengue cases.

Another relevant aspect is a significant decline in the number of cases in 2012 compared with the previous year, which, according to Santo André's Health Department, may have occurred as a result of the many awareness campaigns targeting the general population after the 2011 outbreak.

The year 2013 emerges as the year with the highest number of notified cases. One of the possible explanations is that the months in that year were warmer and wetter all over the state of São Paulo according to meteorological data.

This increasingly common scenario, where winter is no longer a cold and dry season, is a climate change resulting from global warming. ${ }^{10}$

The most industrialized municipalities are the ones with the highest rates of notified dengue cases, which can be explained by the possibility of many cases being imported. As a consequence of industrialization, most workers choose to live in other municipalities and commute daily to/from their jobs. Despite the difficulty in identifying whether the disease is autochthonous or imported, one must consider that these individuals may be infected in the municipality where they live but seek assistance in the municipality where they work, if medical care is more convenient or easily accessed in the latter. Therefore, the lower number of cases notified in municipalities such as Ribeirão Pires and Rio Grande da Serra may be justified.

Regardless of other factors, temperature variations and rainfall intensity affect the reproductive cycle and survival of the vector, which cause changes in its distribution and density, since mosquitoes need humidity and temperatures ranging between $15^{\circ} \mathrm{C}$ and $35^{\circ} \mathrm{C}$ to survive and reproduce. These climate (abiotic) factors have shown an association with the incidence and prevalence of dengue., ${ }^{2,3}$

Many studies have revealed the important role of rainfall in the renewal and oscillations of puddles, conditions that favor egg hatching and the incubation period of the mosquito.

As for temperature, many authors affirm that it interferes with dengue virus incubation period, which drops from 10 to 7 days whenever temperature rises from $27^{\circ} \mathrm{C}$ to $37^{\circ} \mathrm{C} .{ }^{2}$ It is thus clear that temperature and rainfall levels in the months of January, February and March throughout the years were favorable for the development of the virus and that these factors may have contributed to a higher incidence of dengue cases. As the mosquito's life span is around 45 days, the generation born in the beginning of January can infect hosts until February 15, whereas the generation born in the second half of January is able to infect people until March 15. Accordingly, dengue cases appear after weeks of peak temperature and rainfall, a time during which the mosquito can develop and contaminate the population. ${ }^{11}$

Another fact to be considered is the time it takes for each individual to show symptoms of the disease, and, as a result, the time that elapses until these individuals search for assistance at a medical care unit. The greatest number of dengue cases is expected to be reported in the months of February, March, April and May. However, there are many difficulties to establish a "key" seasonal pattern of disease incidence and meteorological variables. Concerning particulate matters, a decrease in the concentration of PM10 is observed from January to May, a critical period when cases are registered most often in the region. Although not confirmed by any study to date, the presence of air pollutants apparently interferes with the life cycle of the Aedes aegypti mosquito.

The relation between health and environment can be clearly seen through the analysis of epidemiological characteristics in areas close to contamination sources and through the identification of adverse environmental factors that are harmful to health. ${ }^{12}$

Investigations on the special conditions that trigger the occurrence of dengue may contribute to the understanding of the role played by social groups in the complex dynamic chain of disease transmission, considering their own limits and possibilities. They can also shed light on more suitable prevention and control strategies in the construction of new indicators by trying the use of multivariate models that take into consideration the spatial distribution of the events. ${ }^{13}$

Variations in climate patterns may influence some disease cycles, favoring and increasing the number of isolated foci of vector-transmitted diseases. Moreover, these changes stimulate the migration of these vectors, cause an increase in epidemics, reduce productivity, and generate an increase in healthcare-related costs. Although the urgency for action is quite clear, so far, little has been done to reverse this scenario. If actions are not taken, the number of dengue cases will continue to escalate and other diseases will gradually emerge as temperatures rise. ${ }^{2}$

From a scientific point of view, it would be advisable to conduct future studies not only on environmental pollution and its influence on the development of the Aedes aegypti mosquito in all of its life cycle phases but also on the definition of strategies for better monitoring of pollutant matters, climate data and dengue cases. The existence of only one climate monitoring station for the entire $\mathrm{ABC}$ area was one of the limitations of our study. Therefore, 
accessing climate data for the analysis of temperature and humidity in all of the municipalities included in our analysis was very difficult.

\section{Conclusion}

We found a statistical association of moisture and PM10 with the reported cases of dengue. There was no statistical correlation between the incidence of dengue and temperature. The presence of air pollutants also interferes with the life cycle of the dengue mosquito, and further studies may reveal important instruments for environmental monitoring and the control of endemic vectors.

\section{Conflict of interest}

The authors declare no conflict of interest.

\section{Resumo}

Fatores climáticos podem influenciar nos casos de notificação de dengue

Objetivo: As alterações globais que têm ocorrido interferem no ambiente natural, influenciando diretamente no crescimento da transmissão de doenças ocasionadas por vetores, das quais se destaca a dengue. O objetivo deste estudo foi compreender as consequências da variabilidade temporal das condições climáticas em relação à ocorrência de dengue na população da região metropolitana de São Paulo, constituída por sete municípios.

Método: A caracterização da tendência temporal da dengue foi realizada por meio da análise dos números de casos de dengue notificados nos anos de 2010 a 2013, de dados meteorológicos (umidade e temperatura) e dados de concentração de poluentes (PM10).

Resultados: Observou-se que os meses de janeiro a abril (de 2010 a 2013) foram os que apresentaram maior número de casos notificados de dengue, com associação estatística entre a umidade e PM10 com os casos de dengue notificados.
Conclusão: Embora a temperatura não assuma, estatisticamente, uma associação com os casos de dengue registrados, foi possível verificar que os picos de temperatura coincidem com os picos epidêmicos de dengue. Seriam interessantes futuros estudos referentes à poluição ambiental e a sua influência no desenvolvimento do mosquito Aedes aegypti em todas as suas fases do ciclo de vida e definição de estratégias para melhor monitoração, campanhas e vigilância.

Palavras-chave: dengue, mosquitos, vetores, clima, mudança climática, poluição ambiental.

\section{References}

1. Silva L, Ferreira VF, Santos S, Silva I. Crescimento da dengue em razão do aquecimento global. Proceedings of 61o Congresso Brasileiro de Enfermagem; Fortaleza, CE, Brazil. 2009 [cited 2015 Sept 20]. Available from: http://www. abeneventos.com.br/anais_61cben/files/02214.pdf.

2. Pereda PC, Alves DCO, Rangel MA. Elementos climáticos e incidência de dengue: teoria e evidência para municípios brasileiros. Rio de Janeiro: Sociedade Brasileira de Econometria, 2011 [cited 2015 Oct 28]. Available from: bibliotecadigital.fgv.br/ocs/index.php/sbe/EBE11/paper/download/2938/1333.

3. FUNASA. Fundação Nacional de Saúde, Ministério da Saúde. Programa Nacional de Controle da Dengue - PNCD. Brasília: Ministério da Saúde; 2002 [cited 2015 Oct 28]. Available from: http://bvsms.saude.gov.br/bvs/ publicacoes/pncd_2002.pdf.

4. Donalísio MR, Glasser CM. Vigilância entomológica e controle de vetores de dengue. Rev Bras Epidemiol. 2002; 5(3):259-79.

5. Glasser CM, Gomes AC. Infestação do estado de São Paulo por Aedes aegypti e Aedes albopictus. Rev Saúde Pública. 2000; 34(6):570-7.

6. Ribeiro AF, Marques GRAM, Voltolini JC, Condino ML. Associação entre incidência de dengue e variáveis climáticas. Rev Saúde Pública. 2006; 40(4):671-6.

7. CETESB - Companhia Ambiental do Estado de São Paulo. Qualidade do ar no Estado de São Paulo. 2014 [cited 2016 Feb 20]. Available from: http:// sistemasinter.cetesb.sp.gov.br/Ar/php/ar_resumo_hora.php

8. Centro de Vigilância Epidemiológica "Prof. Alexandre Vranjac"-CVE [cited 2016 Feb 20]. Available from: http://www.cve.saude.sp.gov.br/.

9. Valsson S, Bharat A. Impact of air temperature on relative humidity: a study. Architecture - Time Space and People. 2011; 38-41.

10. Confalonieri UEC, Marinho DP. Mudança climática global e saúde: perspectivas para o Brasil. Rev Multiciência. 2007; 8:48-64.

11. Viana DV, Ignotti E. The ocurrence of dengue and weather changes in Brazil: a systematic review. Rev Bras Epidemiol. 2013; 16(2):240-56.

12. Rocha JRR, Mariano ZF. Aspectos climáticos e ocorrência de casos de dengue em Jataí - GO. Rev Geonorte. 2012 ;3(5):757-69.

13. Flauzino RF, Souza-Santos R, Oliveira RM. Indicadores socioambientais para vigilância da dengue em nível local. Saúde Soc. 2011; 20(1):225-40. 